\title{
The Effectiveness of Gratification Arrangements as Part of Corruption Crimes in Indonesia: A Theoretical Study in Talcott Parsons Perspective
}

\author{
Teddy Asmara*
}

Faculty of Law, Universitas Swadaya Gunung Jati, Terusan Pemuda Street No. 1A, Cirebon City, Indonesia

\begin{abstract}
This research aims to examine the crime of gratification as part of the criminal act of corruption, which will be seen in Talcott Parson's perspective. Corruption today is a problem for developing countries and has become a world problem that requires integral and transnational handling. One of the most disclosed forms of corruption today is corruption in the form of gratuities. This research method uses normative juridical research with the approach of laws, concepts, and principles and collects primary legal material in the form of Law 20 of 2001 concerning Amendments to Law Number 31 of 1999 concerning Eradication of Corruption Crimes. The results of this study found that the Cybernetics Theory, which Talcott Parsons coined, views the problem of alleged gratification as being strongly influenced by the economic sub-system, this is because a decision that is made has a significant impact on anyone, so it is not surprising if there is a lot of price bargaining. Moreover, the least impact is the cultural sub-system because this sub-system is only the economic sub-system's impact.
\end{abstract}

Keywords: Gratification, Corruption Crime, Talcott Parson, Cybernetics Theory, Indonesia.

\section{INTRODUCTION}

Corruption is a despicable nature and has become a social phenomenon that is detrimental to the state and a violation of the community's social and economic rights. This is understandable given the negative impact caused by corruption. Corruption is a systemic crime related to power that is structurally formed and organized. Corruption can damage the foundations of a nation's personality, mainly due to intellectual corruption (Mauliddar, Din, \& Rinaldi, 2017).

Corruption today is not only a problem for developing countries but has become a world problem that requires integral and transnational handling, therefore in Indonesia, it is agreed as an extraordinary crime. The impact is no longer only for generations but across generations (Suteki, 2015). In the beginning, Law Number 31 of 1999 concerning Eradication of Corruption only discussed corruption as any person who illegally commits an act of enriching himself or another person or a corporation that can harm state finances or the country's economy. This definition was later expanded, one of which is regarding gratification in Law 20 of 2001 concerning Amendments to Law Number 31 of 1999 concerning Eradication of Corruption Crimes.

One of the most disclosed forms of corruption today is corruption in the form of gratuities. Gratification is a

*Address correspondence to this author at the Faculty of Law, Universitas Swadaya Gunung Jati, Terusan Pemuda Street No. 1A, Cirebon City, Indonesia; E-mail: teddyasmara25@yahoo.com gift, reward, or gift by a person who has received services or benefits or by a person who has been or is currently dealing with a public or government institution to obtain a contract. The prohibition of all forms of giving gifts or gratuities to someone related to their capacity as state officials or administrators is nothing new. Gratuities are of particular concern because they are new legislative provisions and need more optimal socialization (Syafira, 2015). The act of giving/gifts to state officials or administrators to influence or benefit from the official's decision, which in Law Number 31 of 1999 jo Law Number 20 of 2001 concerning Corruption Eradication is referred to as "Gratification" (Hafrida, 2013).

Based on the explanation of article 12 B of Law no. 31 of 1999 in conjunction with law No. 20 of 2001, gratification is a gift in a broad sense, including the provision of money, goods, rebates (discounts), commissions, interest-free loans, travel tickets, lodging facilities, travel tours, free medical treatment. And other facilities. Not all gratuities are said to be a criminal act of corruption. The Criminal Code itself distinguishes between 2 (two) groups of criminal acts of bribery, namely the crime of bribes and accepting bribes. The legal subject of the criminal act of giving bribes is the giver of bribes. Meanwhile, the legal subjects of receiving bribes are public servants or state officials who accept bribes. The most recent Gratification cases include bribery for discussion of the 2018 Revised Regional Expenditure Budget for the city of Malang, which dragged 41 Regional Representatives Council and their mayors, alleged bribery of Medan District Court judges in Meliana's blasphemy trial case, and 
alleged bribery of the Minister of Social Affairs of the Republic of Indonesia Idrus. Marham in the Riau-1 Steam Power Plant project.

This phenomenon indicates how the nation's children's morality has moved away from the noble values of Pancasila, transcendental divine values, honesty, justice and humanity, simplicity, unity, and unity. All of them accumulate in the Indonesian nation's soul and personality as the national identity of the Indonesian nation. When the country is suffering from a multi-dimensional moral crisis, it is necessary and time to re-actualize the values of the Pancasila philosophy in the life of the nation and state, which are expected to strengthen morality and behavior as an effort to prevent (prevent) the crime of corruption (Setiawan, 2020).

Various understanding of gratification, which is identified as a-moral, even equates gratification with bribery. Therefore the practice of gratification must be eradicated, even though it is not entirely acceptable to the community because giving and receiving is considered an acceptable norm and even preserved. The giving or receiving of something between the giver and receiver becomes a "problem" when the act of giving and receiving is declared an act of violating criminal law (Bethesda, 2019).

\section{METHODS}

This study using normative juridical research. The definition of normative juridical is a type of research that emphasizes more on library research, where the materials used will be obtained from laws, literature, mass media, which are related to writing materials. The author will also describe the data obtained from the literature in the results of this study. After obtaining the data using normative juridical, the writer describes in words in the study entitled the study of the effectiveness of gratification regulation as part of the corruption in Indonesia: a theoretical study in Talcott Parsons (Simaremare \& Noho, 2021).

The approach method used is a statutory approach, a case approach, and a conceptual approach. The statutory approach is used to carry out tracing, inventory and review of laws and regulations on corruption. The case approach is used to carry out tracing along with legal analysis of various current cases of graft. And the conceptual approach departs from the views and doctrines that are developed in the science of law. doctrine and views are used to see the legal doctrine of thinkers.
The analytical method used refers to laws, existing regulations, looking at existing legal principles and concepts, regulating corruption crimes, and tracing the theoretical study efforts in Talcott Parson's view. Normative juridical research is needed because it is necessary to make an inventory of positive law, discover the principles and basic philosophy (dogma or doctrine) of positive law, and in-concreto legal findings feasible be applied to resolve specific legal cases (Noho, 2019).

\section{RESULTS AND DISCUSSION}

\section{The Effectiveness of Gratification Arrangements as Part of Corruption Crime in the Indonesian Legal System}

So far, the Indonesian legal system still adopts the Dutch colonial legal system (Civil law System). The system initially originated from mainland Europe and is based on Roman law, with its main characteristic being marked by a codification system of the leading legal principles (Kusumohamidjojo, 2015). This system develops in the Indonesian legal system by submitting to the ground norm or Pancasila as its foothold.

A legal system is a formal structure, namely the structure of the rules of law in effect and the principles that underlie it so that it includes both the formal structure and its contents. In its development, apart from being formally viewed, the notion of a legal system can also be viewed as sociological normative, which includes institutions and processes for realizing people's lives. Likewise, it is seen as a social phenomenon in a sociological, cultural study (sociocultural context) or a cultural study of law by examining traditional culture (Hidayat, 2006).

Based on this definition, the legal system is an entire sub-system that is put together, consisting of court institutions, institutions; the legislature as the maker of laws and the judicial system, while the legal component is (Friedman, 1975):

1. Legal structure, namely the part that move within the mechanism, is an institution created by the legal system and has a function to support the legal system's operation. With this legal structure, it is possible to provide services and work regularly;

2. Legal substance, namely the actual results issued by the legal system in the form of legal norms, both regulations, decisions used by law enforcers, and those who are regulated; 
3. Legal culture, which is in the form of ideas, attitudes, hopes, and opinions about law as a whole, determines how the legal system takes a logical place within the cultural framework belonging to the general public.

Through the components of the legal system above, it is possible to trace the eradication of corruption in Indonesia, especially gratuities. In the laws and regulations in Indonesia, gratification is explicitly stated in Law 20 of 2001 concerning Amendments to Law Number 31 of 1999 concerning Eradication of Corruption, including the following articles:

1. Article 12B paragraph (1): Every gratuity to a civil servant or state administrator is considered to be giving a bribe, if it is related to his position and contrary to his obligations or duties, with the following conditions: a. the value of Rp.10,000,000.00 (ten million rupiah) or more, proving that the gratification is not a bribe made by the gratification recipient; $b$. the value of which is less than Rp.10,000,000.00 (ten million rupiahs), proving that the gratuity was bribed by the public prosecutor;

2. Article 12B paragraph (2): Criminal charges for civil servants or state administrators as referred to in paragraph (1) are life imprisonment or imprisonment for a minimum of 4 (four) years and a maximum of 20 (twenty) years, and a fine of at least Rp. 200,000,000.00 (two hundred million rupiah) and a maximum of $\mathrm{Rp}$. $1,000,000,000.00$ (one billion rupiah);

3. Article $12 \mathrm{C}$ paragraph (1): The provisions referred to in Article $12 \mathrm{~B}$ paragraph (1) do not apply if the recipient reports the gratuity they receive to the Corruption Eradication Commission;

4. Article 12C paragraph (2): Submission of reports as referred to in paragraph (1) must be made by the gratification recipient no later than 30 (thirty) working days from the date the gratification is received;

5. Article 12C paragraph (3): The Corruption Eradication Commission, within 30 (thirty) working days from the date of receipt of the report, is obliged to determine that gratuities may belong to the recipient or state property; and
6. Article 12C paragraph (4): Provisions regarding the procedures for submitting reports as referred to in paragraph (2) and determining the status of gratuities as referred to in paragraph (3) are regulated in the Law on the Corruption Eradication Commission.

The elements of the punishment of gratification based on these articles are (Suteki, 2015):

1. Subjects are civil servants or state officials;

2. Receiving gratuities as regulated in the elucidation of Article 12 B paragraph (1);

3. Relating to his position and contrary to his obligations and duties

Thus, the gratification that can be punished is the gratification considered to be a bribe and not a bribe itself. With the provision of gratuities, many public officials, be it judges, legislative members, or executives, have been trapped. We can find these cases in the last two (2) months, including allegations of bribery of members of the Malang City Regional Representative Council, allegations of bribery of Medan District Court judges, and suspicion of bribery by Karimun Regent. If you use the Montesquieu theory of Trias Politica (Yulistyowati \& Pujiastuti, 2016), then these cases can be categorized as follows:

First, the Legislative. The allegation of bribery in the discussion of the 2015 revised regional expenditure budget for the city of Malang caught 41 of 46 members of parliament. Among them is the chairman of the Malang City Regional People's Representative Council to its members. The suspects and defendants are currently under the detention of the Corruption Eradication Commission.

Second, the Executive. Alleged bribery made by Regent Karimun $\mathrm{H}$. regarding the proposed regional financial balancing fund. The Karimun regent was entangled in this case since the case was developed that had ensnared an official of the Ministry of Finance, Yaya Purnomo.

Third, Judicative. The alleged bribery of Ad Hoc Judge Merry Purba was named by the suspect. He is suspected of accepting bribes for the sale of land with state assets totaling upto $S \$ 280$ thousand. Merry has now also been detained for 20 days, at the Corruption Eradication Commission Detention Center in East Jakarta. 
According to Achmad Ali (2009), seeing whether the law made was effective or not could be traced in two ways. First, obedience to the law in general and what factors influence it and second, adherence to a certain legal rule and what factors influence it. If based on what Achmad Ali conveyed, the regulation on gratification has been enforced by the Corruption Eradication Commission by "arresting" officials who do not comply with the rules that have been made and agreed upon.

With his Cyber Theory, Talcott Parsons Looks at the Events of the Effectiveness of the Regulation of Alleged Bribery (Gratification) in Indonesia

In theory, we see that the impact of corruption, especially bribery, is very damaging to the system and society's order. Soejono Karmi, there are still several consequences of corruption, namely (Sina, 2008):

1. Destructive system of society. Conspiracies supported by the public corrupted community norms;

2. The suffering of most people in the economic, administrative, political, and legal sectors;

3. Destruction of a country's economy due to corruption, directly or indirectly, will result in suffering for the majority of society.

Through the approach to cybernetics theory proposed by Talcott Parsons, we will see how the subsystems are related in the case of alleged gratification. Parson is a leading American functionalist, specifically discussing the relationship between individual personalities, social systems, and cultural systems. Initially more or less the same as Weber who focused on the level of individual social action (attention to the social system only appeared later). The emphasis in functionalism is on the requirements that must be met in order for a social system (eg society) to be linked, and not on individual needs (Parsons, 1990).

Talcott Parsons' Cybernetics Theory. In this theory, the social system is a synergy between various social sub-systems that experience interdependence and linkages. That individual behavior is not biological but must be viewed as structured behavior. A person's behavior must be placed within the framework of an overall social system divided into sub-systems (Azhari, 2016). Based on this framework, it can also be interpreted that when the law cannot function properly as a means of integration, social life will experience disruption or disintegration, although to varying degrees. This disturbed state will, in turn, return to equilibrium when the law can perform its optimal function (Surbakti, 2006).

According to Talcott Parson in Rowland Bismark Fernando Pasaribu (2013), four sub-systems carry out the primary function in people's life known as the "action" system, namely the AGIL scheme:

1. Adaptation The economic sub-system carries out. It is related to the alleged gratification that the economic sub-system can influence state officials in running the government bureaucracy. A decision that is made has a significant impact on anyone, so it is not surprising that many price bargaining occurs in the decision;

2. Goal attainment is carried out by the Political sub-system. The political position held by corruptors or would-be corruptors is advantageous because by being in power, all things can be done under their power, even if it breaks through the ethics and moral of politics;

3. Integration The legal sub-system carries out. The legal system is an amalgamation to balance between das sein and das sollen. The alleged gratification of the legal sub-system's existence was carried out based on who ordered the legal product. Because the message ordering legal products results in legal imbalances in society;

4. Latent pattern maintenance is carried out by the cultural sub-system. All of the actions carried out by corrupt officials have an impact on the fabric of society. The structure of society, which at first did not know about bribery (gratification) because of the repetitive pattern, consequently becomes a "culture" for the community.

When viewed from the energy flows above, the economic sub-system occupies the most vital position, followed by the political sub-system, then the legal subsystem (where social is in it), and the cultural subsystem ends. On the other hand, seen from the flow of information (value system), the cultural sub-system is precisely the richest, followed by the legal sub-system, the political sub-system, and ending in the economic sub-system. 
Therefore, it is necessary to restore a state official's spirit as a person who serves the people. According to Fuller in Satjipto Rahardjo (1979), eight values can be realized. These eight values, which he calls the "eight principles of legality," are:

1. There must be rules - regulations beforehand; this means that there is no place for decisions on an ad-hoc basis or for arbitrary action;

2. The regulation must be properly announced;

3. The rules cannot be retroactive;

4. The formulation of regulations must be clear and detailed. The people must understand it;

5. The law should not be required to carry out things that are not possible;

6. Among other regulations, the rules must not be contradicting each other;

7. The rules must be fixed and must not be changed frequently;

8. There must be a match between legal officials' actions and the regulations that have been made.

Based on the explanation above, in the future, it is necessary to encourage an official to consider the aspects put forward by Talcott Parson in order to have a balance. Besides, the values in maintaining legal certainty relate to consistency between the actions of legal officials and the regulations that have been made.

\section{CONCLUSIONS}

The effectiveness of Gratification arrangements in the legal system has a relatively good impact on Indonesia. Article $12 \mathrm{~B}$ paragraphs (1) and (2), and is exempted through Article $12 \mathrm{C}$ paragraphs (1) and (2), (3), and (4) Law 20 of 2001 concerning Amendments to Law Number 31 the Year 1999 Regarding the Eradication of Corruption Crimes gives a message that the mandated position is always on the track by its duties and functions because the supervision of officials is increasing every day. The policies carried out "secretly" in smoothing out the right decision should not be repeated, both at the executive, legislative and judicial levels.
The Cybernetics Theory, which Talcott Parsons coined, views that the economic sub-system very much influences the problem of alleged Gratification, this is because a decision made has a significant impact on anyone, so it is not surprising if in his decision there were many price bargaining and the least effect was cultural sub-system because this sub-system is only an impact of the economic sub-system.

\section{REFERENCES}

Ali, A. (2009). Menguak Teori Hukum (Legal Theory) dan Teori Peradilan (Judicialprudence) Termasuk Interpretasi UndangUndang (Legisprudence). Jakarta: Penerbit Kencana .

Azhari, F. (2016). Dynamics of Social Change and Islamic Law. AlTahrir, 16 (1), 210-211. https://doi.org/10.21154/al-tahrir.v16i1.322

Bethesda, E. (2019). Masyarakt Memandang Gratifkasi Dalam Tindak Pidana. Jurnal Komunikasi Hukum, 5 (2), 64-65. https://doi.org/10.23887/jkh.v5i2.18311

Friedman, L. (1975). The Legal System: Social Science Perspective. New York: Russel Sage Foundation.

Hafrida. (2013). Juridical Analysis of Gratuities and Bribery as Corruption Crimes According to Law Number 31 Year 1999 jo. Law Number 20 of 2001 Concerning The Eradication Of Criminal Acts Of Corruption. Inovatif, 6 (7), 1-2.

Hidayat, A. (2006). Kebebasan Berserikat Di Indonesia (Suatu Analisa Pengaruh Perubahan Sistem Politik Terhadap Penafsiran Hukum). Semarang: Badan Penerbit Universitas Diponegoro.

K, A. T. (2015). Reflection on the Revitalization of Pancasila Values as Ideology in Eliminating Corruption Crimes. Universum, 9 (1), 49.

Kusumohamidjojo, B. (2015). Perbandngan Hukum Kontrak (Comparative Contract Law). Bandung : CV Bandar Maju.

Mauliddar, N., Din, M., \& Rinaldi, Y. (2017). The Gratification As Corruption In Regard With A Report From A Gratification Receiver. Kanun Journal of Legal Studies, 19 (1), 74-75.

Noho, M. D. (2019). Politik Hukum Pengaturan Build Operate Transfer (BOT) Di Indonesia: Di Masa Lalu, Saat Ini, Dan Akan Datang. Jurnal Hukum Media Bhakti, 3 (1), 90. https://doi.org/10.32501/jhmb.v3i1.51

Parsons, T. (1990). Talcot Parsons Dan Pemikirannya, Sebuah Pengantar. Yogyakarta: Tiara Wacana Yogya.

Pasaribu, R. B. (2013). Manusia dan Pandangan Hidup. IImu Budaya Dasar, 264.

Rahardjo, S. (1979). Hukum dan Masyarakat. Bandung: Angkasa.

Setiawan, K. U. (2020). Efforts to Apply the Noble Values of Pancasila During and After the Covid-19 Pandemic. Journal of Theology and Christian Education, 2 (3), 79-89. https://doi.org/10.19166/dil.v2i3.2421

Simaremare, S. P., \& Noho, M. D. (2021). Disharmonized the Regulation of Biological Resources and its Ecosystem in Indonesia. International Journal of Criminology and Sociology, 10, 336

Sina, L. (2008). Impacts and Efforts to Eradicate Corruption and Control of Corruption in Indonesia. Pro Justitia Legal Journal, $26(1), 43$

Surbakti, N. (2006). Implementasi Kebijakan Berwawasan Gender Dalam Penanggulangan Kejahatan. Jurnal IImu Hukum, 9 (2), 205.

Suteki. (2015). Masa Depan Hukum Progresif. Yogyakarta: Thafamedia. 
Syafira, N. (2015). Tinjauan Yuridis Tindak Pidana Menerima Gratifikasi Berdasarkan Undang-Undang Nomor 31 Tahun 1999 Jo Undang-Undang Nomor 20 Tahun 2001 Tentang Pemberantasan Tindak Pidana Korupsi. JOM Fakultas Hukum, II (2), 2
Yulistyowati, E., \& Pujiastuti, E. (2016). Penerapan Konsep Trias Politica dalam Sistem Pemerintahan Republik Indonesia : Studi Komparatif Atas Undang-Undang Dasar Tahun 1945 Sebelum dan Sesudah Amandemen. Jurnal Dinamika Sosial Budaya, 18 (2), 330.

https://doi.org/10.26623/jdsb.v18i2.580

Received on 20-02-2021

Accepted on 26-04-2021

Published on 30-04-2021

https://doi.org/10.6000/1929-4409.2021.10.107

(C) 2021 Teddy Asmara; Licensee Lifescience Global.

This is an open access article licensed under the terms of the Creative Commons Attribution Non-Commercial License (http://creativecommons.org/licenses/by-nc/3.0/) which permits unrestricted, non-commercial use, distribution and reproduction in any medium, provided the work is properly cited. 